\title{
Electrical Stimulation Greatly Increases Settlement, Growth, Survival, and Stress Resistance of Marine Organisms
}

\author{
Thomas J. Goreau \\ Global Coral Reef Alliance, Cambridge, USA \\ Email: goreau@bestweb.net
}

Received 23 May 2014; revised 26 June 2014; accepted 5 July 2014

Copyright (C) 2014 by author and Scientific Research Publishing Inc. This work is licensed under the Creative Commons Attribution International License (CC BY). http://creativecommons.org/licenses/by/4.0/

(c) $\underset{\mathrm{EY}}{0}$ Open Access

\begin{abstract}
Increasing stress from global warming, sea level rise, acidification, sedimentation, pollution, and unsustainable practices have degraded the most critical coastal ecosystems including coral reefs, oyster reefs, and salt marshes. Conventional restoration methods work only under perfect conditions, but fail nearly completely when the water becomes too hot or water quality deteriorates. New methods are needed to greatly increase settlement, growth, survival, and resistance to environmental stress of keystone marine organisms in order to maintain critical coastal ecosystem functions including shore protection, fisheries, and biodiversity. Electrolysis methods have been applied to marine ecosystem restoration since 1976, with spectacular results (Figures 1(a)-(c)). This paper provides the first overall review of the data. Low-voltage direct current trickle charges are found to increase the settlement of corals 25.86 times higher than uncharged control sites, to increase the mean growth rates of reef-building corals, soft corals, oysters, and salt marsh grassan average of 3.17 times faster than controls (ranging from 2 to 10 times depending on species and conditions), and to increase the survival of electrically charged marine organisms-an average of 3.47 times greater than controls, with the biggest increases under the most severe environmental stresses. These results are caused by the fundamental biophysical stimulation of natural biochemical energy production pathways, used by all organisms, provided by electrical stimulation under the right conditions. This paper reviews for the first time all published results from properly designed, installed, and maintained projects, and contrasts them with those that do not meet these criteria.
\end{abstract}

\section{Keywords}

Electrical Stimulation, Corals, Oysters, Settlement, Growth, Survival, Environmental Stress Resistance, Climate Change Adaptation 


\section{Introduction}

Low-voltage direct current trickle charges using Biorock electrolytic technology [1] [2] grow limestone structures of any size or shape in the sea and produce the only self-repairing marine construction material that gets stronger with age [3], and grows breakwaters capable of rapidly growing back severely eroded beaches [4]. But in addition to physical benefits the process also has profound stimulatory effects on all forms of marine life. Biorock structures have been repeatedly shown to greatly increase the settlement, healing, growth, survival, and resistance to stresses such as extreme high temperatures, sedimentation, and eutrophication in stony corals [5]-[9], soft corals [10], oysters [11]-[13], sea grasses [14], and intertidal salt marsh grasses [15]. Many other organisms, including clams, tunicates, sponges, and fishes have also been observed to greatly increase their populations in electrical fields, but few measurements have been made on them to date. This review summarizes the available data on the effects of low-voltage direct current electrical stimulation on growth rates, survival, stress resistance, and physiology, which suggest the mechanism is a completely general one that benefits all organisms [16]. Results from projects that were properly designed, installed, and maintained are included in the main part of this paper. Because understanding the causes of negative results play an important role in the scientific method, projects that do not meet those criteria of proper design, installation, and maintenance are discussed separately.

\section{The Impact of Electrical Stimulation on Marine Organisms}

\subsection{Published Results from Properly Designed, Installed, and Maintained Projects}

The very first Biorock project, built at Grand Isle, Louisiana in 1976, was completely covered by multiple layers of spontaneously settling oysters that grew to adult size in about 3 months [17]. Recent Biorock projects in New York City show dense spontaneous settlement of oysters on rocks near Biorock structures. Nevertheless no controlled studies of oyster settlement have yet been conducted. By the late 1980s it was found that electrically stimulated corals grew 3 - 5 times record rates for their species, even under conditions of severe stress. Since then hundreds of projects have been built all across the Caribbean, Pacific, Indian Ocean, and Southeast Asia, with most projects being in Indonesia, the global center of marine biodiversity. While slowly growing Biorock structures have been densely covered with hundreds of spontaneously recruiting corals [5] [16], only two studies have documented coral settlement on them [5] [6]. When these are compared to spontaneous recruitment of corals in natural habitats in the same units (recruits per square meter per month) the rates of settlement on electrically charged Biorock are found to be 1 to 4 orders of magnitude greater (Figure 2(a)), with a mean of 25.86 times higher than those reported from field settling experiments.

Growth rates of reef building hard corals [5]-[9], gorgonian soft coral [10], oysters [11]-[13], and salt marsh grass (Spartina alterniflora) [15] have been quantitatively compared on Biorock with identical clones off Biorock in the same habitat. The results show that the electrically stimulated organisms grow typically 2 to 10 times faster (Figure 2(b)), with a mean of 3.17 times greater than controls. In addition hard and soft corals that have been collected naturally broken and badly damaged are observed to heal completely, release little or no mucus, and regain bright color and polyp extension within a day, while controls remain pale and continue to look injured and release mucus for two weeks [16]. Corals in electrical fields are observed to bud and branch more densely [8] [18]. This is reminiscent of the well known role of DC electrical fields in healing ruptured cellular membranes and cuts in the skin of organisms: if the polarity is correct the cut rapidly heals and closes, while if it is reversed the cut opens up [19].

Survival of hard corals [6]-[9], soft corals [10], oysters [11]-[13], and salt marsh grass [15] in electrical fields compared to un-electrified controls also show many times higher survival (Figure 2(c)), with a mean of 3.47 times higher than controls. This is especially the case in extreme stress conditions from excessively high temperatures, sedimentation, or eutrophication, when almost all the controls die, but most of the electrically charged organisms survive. For example in the severe 1998 Maldives bleaching event Biorock reefs had 16 to 50 times higher coral survival than surrounding reefs, and every single control coral transplanted onto cement structures died [20]. In the 2010 Thailand bleaching events corals bleached less (in some cases not at all), recovered faster, and had much higher survival than the same species of corals on surrounding reefs [21]. Similar results have been seen with oysters [13], salt marsh grass [15], and seagrass [14]. Control oysters in New York City nearly all died over a severe winter, and the shells of the survivors shrank in size because they were etched and dissolved from acidity caused by increased $\mathrm{CO}_{2}$ solubility in cold water. In contrast Biorock oysters continued to 


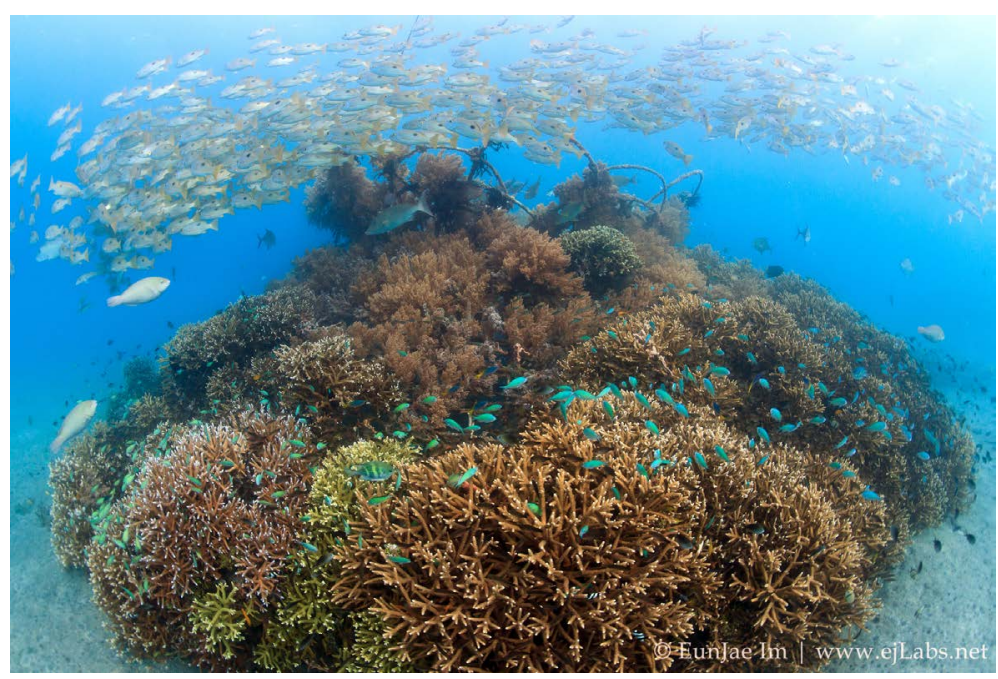

(a)

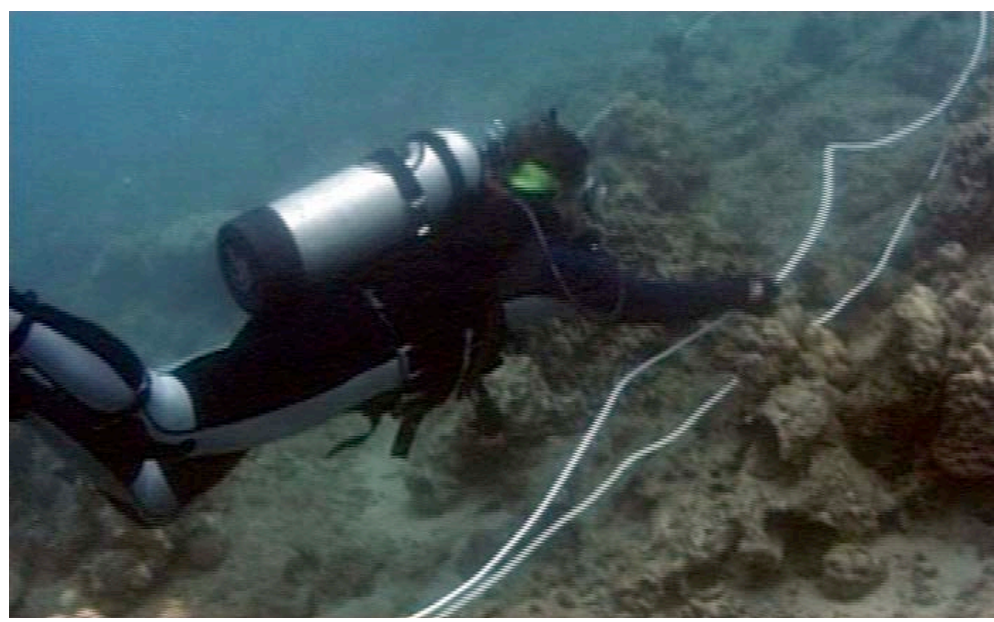

(b)

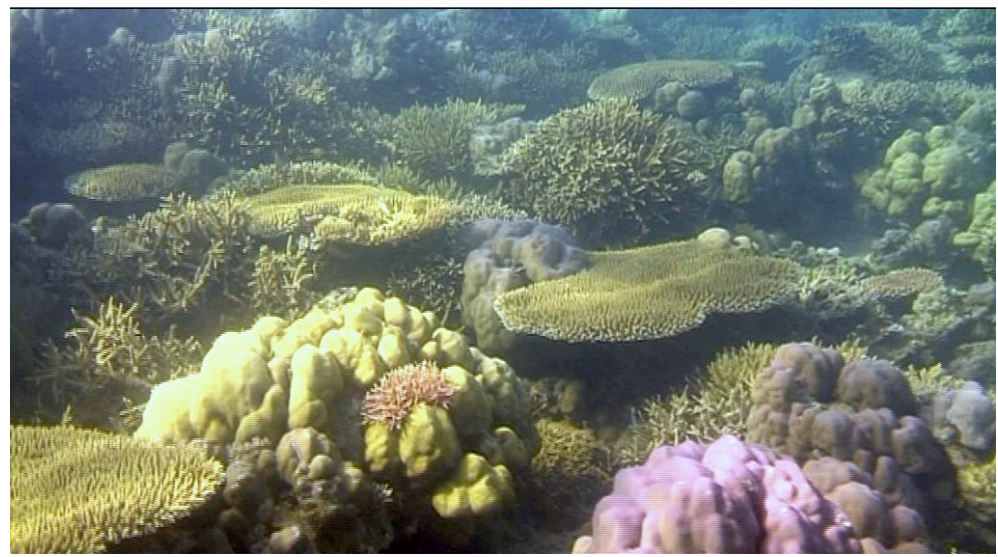

(c)

Figure 1. (a) Five-year-old Biorock electrical reef grown on formerly barren sand in Pemuteran, Bali, Indonesia, showing prolific coral growth and fish populations (photograph by EunJae Im); (b) Site at Pemuteran, Bali in 2001 at start of project (photograph by Rani Morrow-Wuigk); (c) Same location 10 years later in 2001 (photograph by Rani Morrow-Wuigk). 


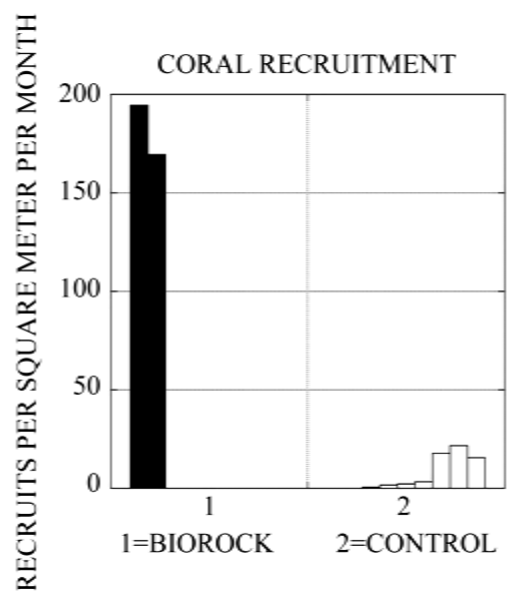

(a)

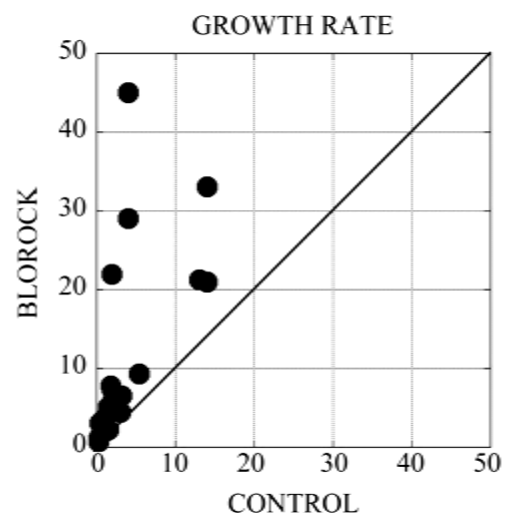

(b)

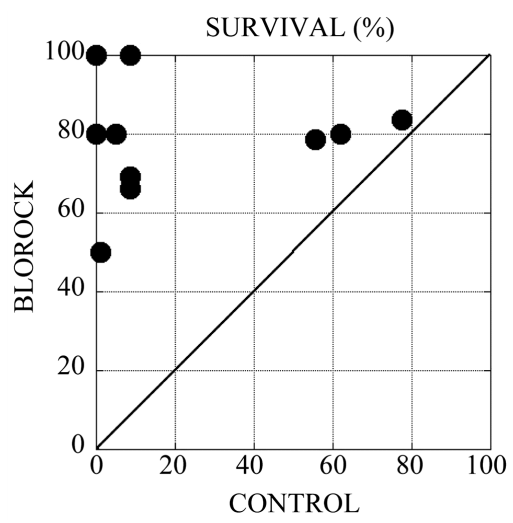

(c)

\begin{abstract}
Figure 2. (a) Coral recruitment rates on Biorock limestone substrates [5] [6] versus natural limestone rock and artificial substrates (full list of citations given in [16]). Biorock coral settlement rates range from around 1 to 4 orders of magnitude higher when compared in the same units, spontaneously settling juvenile corals per square meter per month. The mean settlement rate on Biorock was 25.86 times higher than controls; (b) Linear growth rates of electrically stimulated corals [5]-[9], gorgonians [10], oysters [11]-[13], and salt marsh grass [15] versus controls. Each dot represents the average value of times series on populations of treated and control organisms. Mean growth rates of electrically stimulated organisms over the same time interval were 3.165 times higher than identical controls without electrical fields, ranging between 2 - 10 times higher. All points above the 1:1 line indicate electrical stimulation, to an extent indicated by the slope to the origin; (c) Survival of electrically stimulated corals [6]-[9] [20], oysters [11]-[13], gorgonians [10], and salt marsh grass [15] versus controls. Mean survival of electrically stimulated organisms was 3.47 times higher than controls, especially under severe stress conditions resulting in nearly total mortality of controls.
\end{abstract}

grow throughout the normally dormant period, and their shells were shiny with no signs of dissolution from acidity [13]. This is in part because the Biorock electrolytic process generates net alkalinity, and so counteracts acidification [3].

A comparison of 6 genera of corals grown on Biorock with genetically identical clones in the same habitat [22] showed that electrically stimulated corals had higher densities of the symbiotic alga Symbiodinium sp. (Figure 3(a)), even higher Symbiodinium cell division rates as measured by mitotic indices (Figure 3(b)), but had generally lower chlorophyll per Symbiodinium cell (Figure 3(c)). This is analogous to the lowered chlorophyll content of corals exposed to high light, which is interpreted as a mechanism to prevent excessive photosynthetic production and symbiotic alga growth [23]-[25]. The greatly increased growth rate of corals with electrical stimulation appears to occur despite less dependence on the symbiotic algae, and therefore is a direct effect of the electrical field itself. 


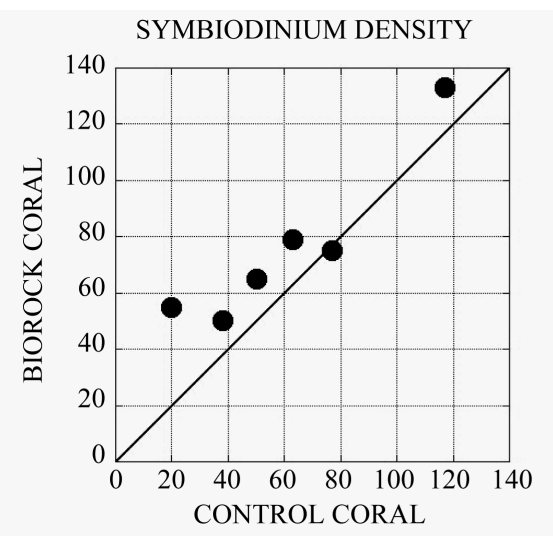

(a)

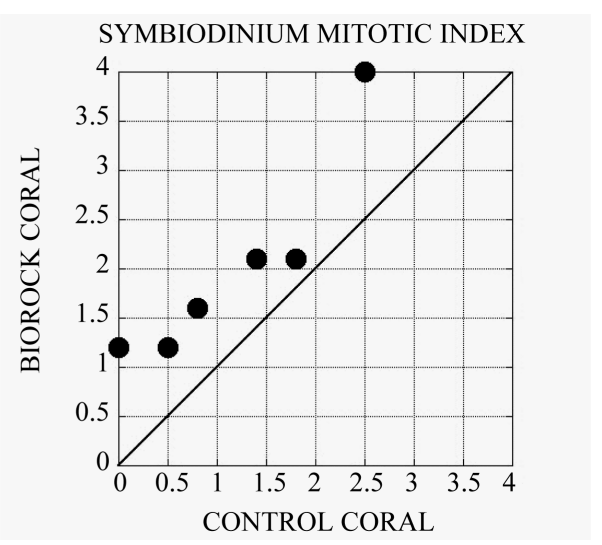

(b)

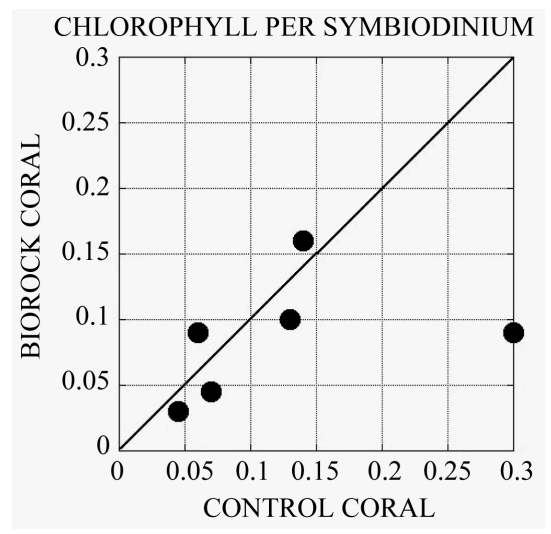

(c)

\begin{abstract}
Figure 3. (a) Density of Symbiodinium sp. in corals grown on Biorock versus the genetically identical mother colony from which they were transplanted in the same environment nearby [22]. Electrically stimulated corals had on an average 1.25 times higher symbiotic alga densities than controls; (b) Cell division rate of Symbiodinium sp. as measured by mitotic indices (percentage of dividing alga cells) in Biorock corals versus controls [22]. Electrically stimulated corals have an average of 1.74 times higher cell division rates, and presumably growth; (c) Chlorophyll content per Symbiodinium cell in Biorock corals versus controls. Birock corals have an average of 0.69 times less chlorophyll per symbiotic alga cell as controls [22]. This suggests that their productivity is being suppressed, as happens in high light [23]-[25]. Since coral calcification is normally proportional to photosynthesis of Symbiodinium sp. [26], this implies that the higher growth rate of Biorock corals is not due to higher photosynthesis, but due to greater energy availability provided by the electrical field.
\end{abstract}

All of these phenomena indicate that electrical fields in the right range greatly stimulate the health of marine organisms. These effects are not residual, they occur only when the electrical field is on (Figure 4(a)). These results are no surprise, since all forms of life from bacteria on up maintain a roughly tenth of a volt potential difference between the outside of the cell and the inside, and use electron and proton flow along this voltage gradient to make ATP and NADP, the fundamental energy and reducing currencies of all life. ATP production and protein synthesis are both directly stimulated by DC electrical currents over a very broad range spanning orders of magnitude [27], increasing with current to a maximum and then decreasing at excessive levels (Figure 4(b)).

\title{
2.2. Results from Improperly Designed Experiments
}

This section discusses published results from projects that do not meet the criteria of proper training, materials, design, installation, and maintenance according to the inventors of the electrical stimulation method. All have failed to get the results achieved by those with proper training and materials, for several different reasons. As 


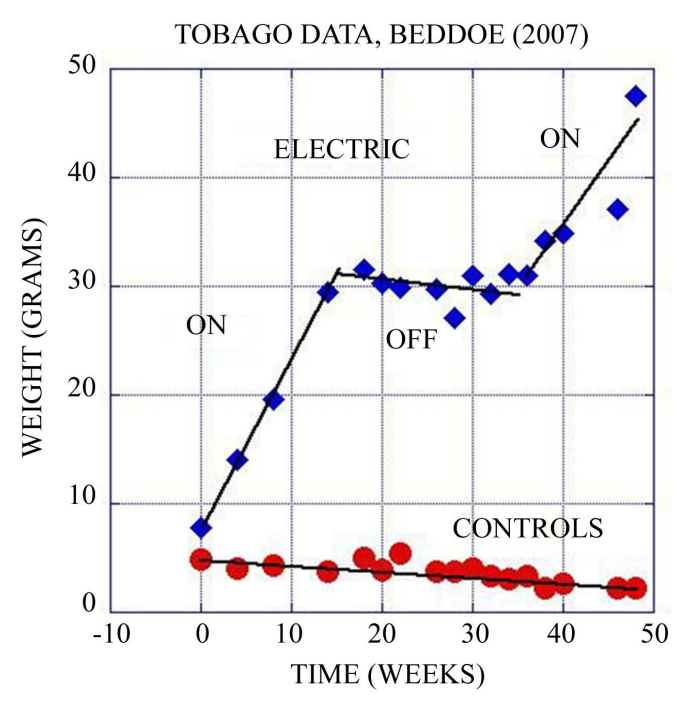

(a)

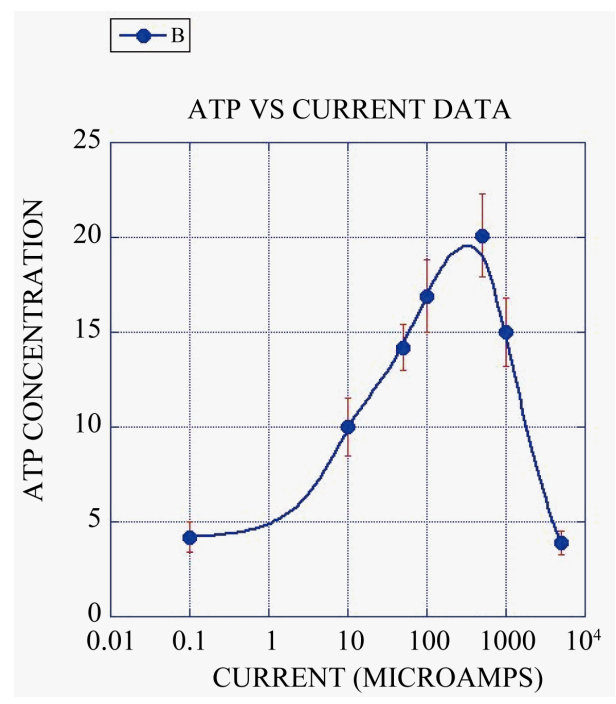

(b)

Figure 4. (a) Control corals grown in extremely poor water quality habitat steadily lost weight while electrified corals grew very fast over 16 weeks. When the power was cut they started to decline like the controls, but immediately resumed growth when power was restored. This shows that coral growth stimulation is a property of the actively applied field, and does not have residual effects. Data from [28] plotted in [16]; (b) ATP concentration in micromoles per gram of tissue is shown as a function of electrical current. A five times increase in ATP is seen at the peak. Data from [27], plotted in [16].

there are several different causes for their failure to achieve prime results, these inappropriate projects are reviewed below by major categories of the flaws in their design or execution.

\subsubsection{Mistake -1: Current Reversed}

In these projects the power leads are connected backwards. Instead of the cathode being protected from corrosion, it rusts very rapidly instead, and the anode, instead of being clean, is instead heavily overgrown by rapid growth of soft minerals. Sometimes it takes months before they realize their mistake, and often the error was only recognized much too late when the author visited and pointed it out. These mistakes can easily be prevented by promptly sending photos for advice. In some cases reports based on this mistake have been published claiming that the method is a total failure. A report by the Texas A\&M University Galveston Coastal Geology Laboratory was paid for the State of Texas General Lands Office (GLO), in order to see if electrical methods could protect steel with mineral coatings, as had been shown by Hilbertz in the 1970s. Texas A\&M found instead that the charged structures rusted even faster than the controls! They never realized their mistake, nor apparently did Texas GLO.

\subsubsection{Mistake 0: No Current}

This can result from power supply failure or from cable breakage.

In some of these cases the project was properly designed and installed, but those running the project failed to realize that it was not under power and send photos to the author for confirmation and advice on how to fix it. Some of these continued making measurements for up to year not realizing that the project was not under power, and the mistake was only realized afterwards when they finally sent the first photographs to the author, who immediately recognized they were not receiving electrical current. That is why even trained groups are advised to send frequent photos for advice.

Other cases were by untrained imitators using incorrect design and materials. These failures were largely caused by power supplies burning out, electrical cables breaking, or bad contacts. Most such failures were caused by extreme storm events, such as hurricanes, typhoons, and cyclones, and were not properly diagnosed or repaired. In other cases they resulted from deliberate destruction by people running boats over the cables, breaking cables by dragging anchors over cables, by people dumping anchors on top of projects accidentally or 
deliberately, or saboteurs who cut cables for bizarre reasons of their own, usually involving a personal grudge against a local partner rather than the project itself. Unfortunately several projects that received no current resulted in published theses and papers.

One example is a thesis project by Zaidy Khan at the University of the South Pacific, which found no difference in growth rates of corals on structures which were thought to be under power but which in fact were not, and control structures known to receive no power.

The same error occurred in a thesis project by Andrew Taylor of James Cook University, supervised by Bette Willis, who sought to compare coral growth on structures with and without power. Taylor did not build any electrified structures, he simply used one of our field sites without permission, which his thesis advisor did not seem to realize was fundamentally unethical. The structure he thought was under power was in fact not, due to a burned out power supply that had not been repaired or replaced. In addition Taylor's control corals died from disease, but a poster was presented anyway at the International Coral Reef Symposium claiming that Biorock corals did not grow faster than controls.

Another experiment done by Bogor University at Pramuka Island in the Seribu Islands north of Jakarta was victim of deliberate turning off of the power. The local power supply was in a commercial restaurant that was paid for supplying power, but which in fact turned the power off except during short visits by students making measurements. The interpretation of several Master's theses was compromised by failure to realize what had happened until later.

In several cases groups in places like Thailand, the Philippines, Germany, Japan, the United States, and other places, who falsely claim to be trained in Biorock methods have been making unauthorized projects that have been complete failures. Their pitiful results are an obvious failure to all visitors, and an embarrassment because the imitators then say the method doesn't work, not that they aren't trained to do it properly.

\subsubsection{Mistake 1: Current Too Low}

This mistake results from powering too large an area with too small a power source, or failure to recognize that cables are broken or inadequate. One example comes from Terlouw [29], who reports measurements made on a project in Ko Tao, Thailand that was partially installed, but whose installation was never completed to standards. As a result of inadequate and broken cables the project received only a little power in the first year. In the second year new cables were installed and a failed power supply replaced so the project received power, but in the third year the cables broke and or the power supply failed, so only a small trickle or no power reached the project. These conditions were identified by the author from photographs sent from the project, but were not recognized by Terlouw, who reported that corals on Biorock grew faster than control corals by a factor of 1.54 in Year One, by a factor of 5.04 in Year Two, and by a factor of 1.33 in Year Three. Terlouw, not recognizing the cause of the variations, suggested that benefits are mixed, but our interpretation is that the higher results in Year 2 are due to that being the only year with adequate power, while Year 1 and Year 3 were underpowered, resulting in lower rates.

A similar mistake was made with oysters by Piazza et al. [30]. In this particular case the oysters thought to be getting electrical current were in fact getting almost none at all, because flawed experimental design concentrated the current onto fresh pieces of bare steel. Piazza et al. found that the oysters that they incorrectly thought to be under power grew only 1.15 times faster than controls.

\subsubsection{Mistake 2: Current Too High}

Over-charging has been known to cause negative effects from the very start, but most groups that set up experiments without proper training or materials use high power to get quick results. As shown in Figure 4(b) of this paper, excessive current causes negligible benefits, and if too high, causes negative effects, killing corals. Unfortunately most of those who get negative results due to overcharging do not realize their error, and many of them have published their results anyway. This mistake is the cause of the very poor results reported by Schuhmacher, Schillak, Van Treeck, Sabater, Yap, Eggeling, and their colleagues [31]-[39]. Since these authors did not realize their mistakes and published negative or minor results, it has been widely claimed that the method does not work, but in fact their poor results were entirely due to lack of proper training, experimental design, materials, etc. Such mistakes are even worse when done in a closed system tank. As a result of their overcharging the corals had only very small increases in growth rates, or they bleached and failed to grow entirely, or died. 


\subsubsection{Mistake 3: Ethical}

Borrell et al. [40] [41] reported that one coral species grows a bit faster with electricity but that another species had its growth reduced and inhibited by the electrical field [40] [41]. In fact, the alleged reduction of one species' growth was for a completely different reason: terminal phase male parrotfish established their breeding territories on the Biorock project, and marked them by biting off all the growing tips of that one species only, while ignoring them in the control site. The author of this paper personally set that project up, and documented the cause, but this was completely and knowingly ignored by the authors of the report, causing deceptive and false conclusions.

\section{Conclusions}

These results all point in the same direction: low-voltage trickle charges can greatly enhance the health of marine organisms. Voltage gradients in the right range appear to create the ideal biophysical conditions for the creation of biochemical energy, stimulating healing, growth, survival, and resistance to stress. The external field maintains the cell membrane gradient and greatly reduces the need for cells to spend a large part of their energy pumping electrons, protons, and ions to maintain the gradient, freeing this energy for metabolism, growth, and resisting environmental stress.

Unfortunately many people copying the Biorock method think they can do so without training. The results of improperly designed, installed, and maintained projects set up by people without training using improper materials always fail to replicate the results of projects by trained people using approved methods and materials, for several obvious reasons. These people inevitably blame the technology itself and not their lack of training.

Almost every data point in these graphs represents populations of different species grown in the field under different electrical conditions, most of which are likely to be suboptimal. For example oyster growth rates next to a former toxic waste dump in New York City increased with current, up to 10 fold (NB, length increase only, the volume increase is a thousand fold), even though they were getting power less than a quarter of the time, and probably would have grown even faster with more power [13]. Much more work is needed to find out the optimal conditions, which are likely to be subtly different for each species. It has not escaped our attention that because membrane electro-chemical gradient-driven energy production is universal among all cellular life, going back to the last common ancestor, the method will apply to all organisms, although the effects and best conditions will depend on the electrical conductivity of their medium.

Maintaining ecosystem services in the face of accelerating global climate change will require methods that increase growth, survival, and resistance to escalating stress. These results indicate that the Biorock process is unique in accelerating settlement, growth, healing, branching, survival, and resistance to environmental stress. This allows marine organisms to be kept alive under conditions that would otherwise kill them, and enables entire complex ecosystems to be restored in a short period of time in places where there is no natural recovery (Figure 1). The Biorock electrolysis method, by stimulating the natural energy production mechanism, is the only ecological restoration method known that can maintain and restore marine ecosystems under conditions of accelerating global warming, sea level rise, ocean acidification, sedimentation, and excessive nutrient inputs, especially under severe stress where all other methods fail. It is urgent that the method should be optimized and applied on a large scale as soon as possible, especially in coral reefs, the ecosystem most threatened by global warming [42] [43], and in extending oyster reefs and salt marshes seaward to reduce coastal damage caused by global sea level rise.

\section{Acknowledgements}

This paper is dedicated to the late architect Wolf Hilbertz, who invented the electrolysis method in 1976 to produce building materials from the sea, and who worked with the author from 1987 until his death in 2007 to apply and perfect the technology. I thank all of our many students from all over the globe who have worked with us on hundreds of projects, and Robert K. Trench and an anonymous reviewer for helpful suggestions.

\section{References}

[1] Hilbertz, W. (1979) Electrodeposition of Minerals in Sea Water: Experiments and Applications. IEEE Journal on Oceanic Engineering, 4, 1-19. http://dx.doi.org/10.1109/JOE.1979.1145428 
[2] Hilbertz, W. and Goreau, T.J. (1996) Method of Enhancing the Growth of Aquatic Organisms and Structures Created Thereby. Patent 5543034. United States Patent Office.

[3] Goreau, T.J. (2012) Marine Electrolysis for Building Materials and Environmental Restoration. In: Kleperis, J. and Linkov, V., Eds., Electrolysis, InTech Publishing, Rijeka, 273-290.

http://www.intechopen.com/books/show/title/electrolysis

[4] Goreau, T.J., Hilbertz, W., Hakeem, A.A.A., Sarkisian, T., Gutzeit, F. and Spenhoff, A. (2012) Restoring Reefs to Grow Back Beaches and Protect Coasts from Erosion and Sea Level Rise. In: Goreau, T.J. and Trench, R.K., Eds., Innovative Methods of Marine Ecosystem Restoration, CRC Press, Boca Raton, 11-34.

http://dx.doi.org/10.1201/b14314-4

[5] Goreau, T.J. and Hilbertz, W. (2012) Reef Restoration Using Seawater Electrolysis in Jamaica. In: Goreau, T.J. and Trench, R.K., Eds., Innovative Methods of Marine Ecosystem Restoration, CRC Press, Boca Raton, 35-45. http://dx.doi.org/10.1201/b14314-5

[6] Jompa, J., Suharto, Anpusyahnur, E.M., Dwija, P.N. Subagio, J., Alimin, I., Anwar, R., Syamsuddin, S., Radiman, T. H.U., Triyono, H., Sue, R.A. and Soeyasa, N. (2012) Electrically Stimulated Corals in Indonesia Reef Restoration Projects Show Greatly Accelerated Growth Rates. In: Goreau, T.J. and Trench, R.K., Eds., Innovative Methods of Marine Ecosystem Restoration, CRC Press, Boca Raton, 47-58. http://dx.doi.org/10.1201/b14314-6

[7] Bakti, L.A.A., Virgota, A., Damayanti, L.P.A., Radiman, T.H.U., Retnowulan, A., Hernawati, Sabil, A. and Robbe, D. (2012) Biorock Reef Restoration in Gili Trawangan, North Lombok, Indonesia. In: Goreau, T.J. and Trench, R.K., Eds., Innovative Methods of Marine Ecosystem Restoration, CRC Press, Boca Raton, 59-80. http://dx.doi.org/10.1201/b14314-7

[8] Zamani, N.P., Abdallah, K.I. and Subhan, B. (2012) Electrical Current Stimulates Coral Branching and Growth in Jakarta Bay. In: Goreau, T.J. and Trench, R.K., Eds., Innovative Methods of Marine Ecosystem Restoration, CRC Press, Boca Raton, 81-89. http://dx.doi.org/10.1201/b14314-8

[9] Nitzsche, J. (2012) Electricity Protects Coral from Overgrowth by an Encrusting Sponge in Indonesia. In: Goreau, T.J. and Trench, R.K., Eds., Innovative Methods of Marine Ecosystem Restoration, CRC Press, Boca Raton, 91-103. http://dx.doi.org/10.1201/b14314-9

[10] Fitri D. and Rachman, M.A. (2012) Gorgonian Soft Corals Have Higher Growth and Survival in Electrical Fields. In: Goreau, T.J. and Trench, R.K., Eds., Innovative Methods of Marine Ecosystem Restoration, CRC Press, Boca Raton, 105-111. http://dx.doi.org/10.1201/b14314-10

[11] Karissa, P.T., Sukardi, Priyono, S.B., Mamangkey, G.F. and Taylor, J.J.U. (2012) Utilization of Low-Voltage Electricity to Stimulate Cultivation of Pearl Oysters Pinctada maxima (Jameson). In: Goreau, T.J. and Trench, R.K., Eds., Innovative Methods of Marine Ecosystem Restoration, CRC Press, Boca Raton, 131-139. http://dx.doi.org/10.1201/b14314-12

[12] Berger, N., Haseltine, M., Boehm, J.T. and Goreau, T.J. (2012) Increased Oyster Growth and Survival Using Biorock Technology. In: Goreau, T.J. and Trench, R.K., Eds., Innovative Methods of Marine Ecosystem Restoration, CRC Press, Boca Raton, 141-150. http://dx.doi.org/10.1201/b14314-13

[13] Shorr, J., Cervino, J., Lin, C., Weeks, R. and Goreau, T.J. (2012) Electrical Stimulation Increases Oyster Growth and Survival in Restoration Projects. In: Goreau, T.J. and Trench, R.K., Eds., Innovative Methods of Marine Ecosystem Restoration, CRC Press, Boca Raton, 151-159. http://dx.doi.org/10.1201/b14314-14

[14] Vaccarella, R. and Goreau, T.J. (2012) Restoration of Seagrass Mats (Posidonia oceanica) with Electrical Stimulation. In: Goreau, T.J. and Trench, R.K., Eds., Innovative Methods of Marine Ecosystem Restoration, CRC Press, Boca Raton, Florida, 161-167. http://dx.doi.org/10.1201/b14314-15

[15] Cervino, J., Gjoza, D., Lin, C., Weeks, R. and Goreau, T.J. (2012) Electrical Fields Increase Salt Marsh Survival and Growth and Speed Restoration in Adverse Conditions. In: Goreau, T.J. and Trench, R.K., Eds., Innovative Methods of Marine Ecosystem Restoration, CRC Press, Boca Raton, Florida, 169-178. http://dx.doi.org/10.1201/b14314-16

[16] Goreau, T.J. (2012) Marine Ecosystem Electrotherapy: Practice and Theory. In: Goreau, T.J. and Trench, R.K., Eds., Innovative Methods of Marine Ecosystem Restoration, CRC Press, Boca Raton, 263-290. http://dx.doi.org/10.1201/b14314-20

[17] Goreau, T.J. (2012) Innovative Methods of Marine Ecosystem Restoration: An Introduction. In: Goreau, T.J. and Trench, R.K., Eds., Innovative Methods of Marine Ecosystem Restoration, CRC Press, Boca Raton, 5-10. http://dx.doi.org/10.1201/b14314-3

[18] Stromberg, S.M., Lundalv, T. and Goreau, T.J. (2010) Suitability of Mineral Accretion as a Rehabilitation Method for Cold-Water Coral Reefs. Journal of Experimental Marine Biology and Ecology, 395, 153-161. http://dx.doi.org/10.1016/j.jembe.2010.08.028

[19] Zhao, M., Song, B., Pu, J., Wada, T., Reid, B., Tai, G., Wang, F., Guo, A., Walczysko, P., Gu, Y., Sasaki, T., Suzuki, A., Forrester, J.V., Bourne, H.R., Devreotes, P.N., McCaig, C.D. and Penninger, J.M. (2006) Electrical Signals Control 
Wound Healing through Phosphatidylinositol-3-OH Kinase- $\gamma$ and PTEN. Nature, 442, 457-460. http://dx.doi.org/10.1038/nature04925

[20] Goreau, T.J. and Hilbertz, W. (2005) Marine Ecosystem Restoration: Costs and Benefits for Coral Reefs. World Resource Review, 17, 375-409.

[21] Goreau, T.J. and Sarkisian, T. (2010) Electric Coral Reef Restoration in Thailand. Asia Pacific Coral Reef Symposium, 2, 100.

[22] Goreau, T.J., Cervino, J. and Pollina, R. (2004) Increased Zooxanthellae Numbers and Mitotic Indices in Electrically Stimulated Corals. Symbiosis, 37, 107-120.

[23] Wethey, D.S. and Porter, J.W. (1976) Sun and Shade Differences in Productivity of Reef Corals. Nature, 262, $281-282$. http://dx.doi.org/10.1038/262281a0

[24] Porter, J.W., Muscatine, L., Dubinsky, Z. and Falkowski, P.G. (1984) Primary Production and Adaptation in Light- and Shade-Adapted Corals of the Symbiotic Coral Stylophora pistillata. Proceedings of the Royal Society of London B, 222, 161-180. http://dx.doi.org/10.1098/rspb.1984.0057

[25] Hennige, S.J., Suggett, D.J., Warner, M.E., McDougall, K.E. and Smith, D.J. (2009) Photobiology of Symbiodinium Revisited: Bio-Physical and Bio-Optical Signatures. Coral Reefs, 28, 179-195. http://dx.doi.org/10.1007/s00338-008-0444-x

[26] Goreau, T.F. and Goreau, N.I. (1959) The Physiology of Skeleton Formation in Corals. II. Calcium Deposition by Hermatypic Corals under Various Conditions in the Reef. Biological Bulletin, 117, 239-250. http://dx.doi.org/10.2307/1538903

[27] Cheng, N., Van Hoof, H., Bockx, E., Hoogmartens, M.J., Mulier, J.C., De Ducker, F.J., Sansen, W.J. and De Loecker, W. (1982) The Effects of Electric Currents on ATP Generation, Protein Synthesis, and Membrane Transport in Rat Skin. Clinical Orthopaedics and Related Research, 171, 264-272.

[28] Beddoe, L., Goreau, T.J., Agard, J.B.R., George, M. and Phillip, D.A.T. (2010) Electrical Enhancement of Coral Growth: A Pilot Study. In: Lawrence, A. and Nelson, H.P., Eds., Proceedings of the 1st Research Symposium on Biodiversity in Trinidad and Tobago, University of the West Indies, 116-122.

[29] Terlouw, G. (2012) Coral Reef Rehabilitation on Koh Tao, Thailand: Assessing the Success of a Biorock Coral Reef. Vrije Universiteit, Amsterdam, 31.

[30] Piazza, B.P., Piehler, M.K., Grossman, B.P., La Peyre, M.K. and La Peyre, J.L. (2009) Oyster Recruitment and Growth on an Electrified Structure in Grand Isle, Louisiana. Bulletin of Marine Science, 84, 59-66.

[31] Schuhmacher, H. (2002) Use of Artificial Reefs with Special Reference to the Rehabilitation of Coral Reefs. Bonner Zoologische Monographien, 50, 81-108.

[32] Schuhmacher, H. and Schillak, L. (1994) Integrated Electrochemical and Biogenic Deposition of Hard Material-A Nature-Like Colonisation Substrate. Bulletin of Marine Science, 55, 672-679.

[33] Schuhmacher, H., Van Treeck, P., Eisinger, M. and Paster, M. (2000) Transplantation of Coral Fragments from Ship Groundings on Electro-Chemically Formed Reef Structures. Proceedings of the 9th International Coral Reef Symposium, Bali, 2, 23-27.

[34] Van Treeck, P. and Schuhmacher, H. (1997) Initial Survival of Coral Nubbins Transplanted by a New Coral Transplantation Technology-Options for Reef Rehabilitation. Marine Ecology Progress Series, 150, 287-292. http://dx.doi.org/10.3354/meps150287

[35] Van Treeck, P. and Schuhmacher H. (1998) Mass Diving Tourism-A New Dimension Calls for New Management Approaches. Marine Pollution Bulletin, 37, 499-504. http://dx.doi.org/10.1016/S0025-326X(99)00077-6

[36] Van Treeck, P. and Schuhmacher, H. (1999) Artificial Reefs Created by Electrolysis and Coral Transplantation: An Approach Ensuring the Compatibility of Environmental Protection and Diving Tourism. Estuarine, Coastal and Shelf Science, 49, 75-81.

[37] Sabater, M.G. and Yap, H.T. (2002) Growth and Survival of Coral Transplants with and without Electrochemical Deposition of $\mathrm{CaCoB}_{3} \mathrm{~B}$. Journal of Experimental Marine Biology and Ecology, 272, 131-146. http://dx.doi.org/10.1016/S0022-0981(02)00051-5

[38] Sabater, M.G. and Yap, H.T. (2004) Long-Term Effects of Mineral Accretion on Growth, Survival and Corallite Properties of Porites cylindrica Dana. Journal of Experimental Marine Biology and Ecology, 311, 355-374. http://dx.doi.org/10.1016/j.jembe.2004.05.013

[39] Eggeling, D. (2006) Electro-Mineral Accretion Assisted Coral Growth: An Aquarium Environment. Townsville Aquarium, Queensland, 21.

[40] Borell, E.M. (2008) Coral Photophysiology in Response to Thermal Stress, Nutritional Status and Seawater Electrolysis. Centre for Tropical Biology, University of Bremen, Bremen, 134. 
[41] Borell, E.M., Romatzki, S.B.C. and Ferse, S.C.A. (2009) Differential Physiological Responses of Two Congeneric Scleractinian Corals to Mineral Accretion and an Electrical Field. Coral Reefs, 29, 191-200.

[42] Goreau, T.J. and Hayes, R.L. (2005) Global Coral Reef Bleaching and Sea Surface Temperature Trends from Satellite-Derived Hotspot Analysis. World Resource Review, 17, 254-293.

[43] Goreau, T.J., Hayes, R.L. and McAllister, D. (2005) Regional Patterns of Sea Surface Temperature Rise: Implications for Global Ocean Circulation Change and the Future of Coral Reefs and Fisheries. World Resource Review, 17, 350374. 
Scientific Research Publishing (SCIRP) is one of the largest Open Access journal publishers. It is currently publishing more than 200 open access, online, peer-reviewed journals covering a wide range of academic disciplines. SCIRP serves the worldwide academic communities and contributes to the progress and application of science with its publication.

Other selected journals from SCIRP are listed as below. Submit your manuscript to us via either submit@scirp.org or Online Submission Portal.
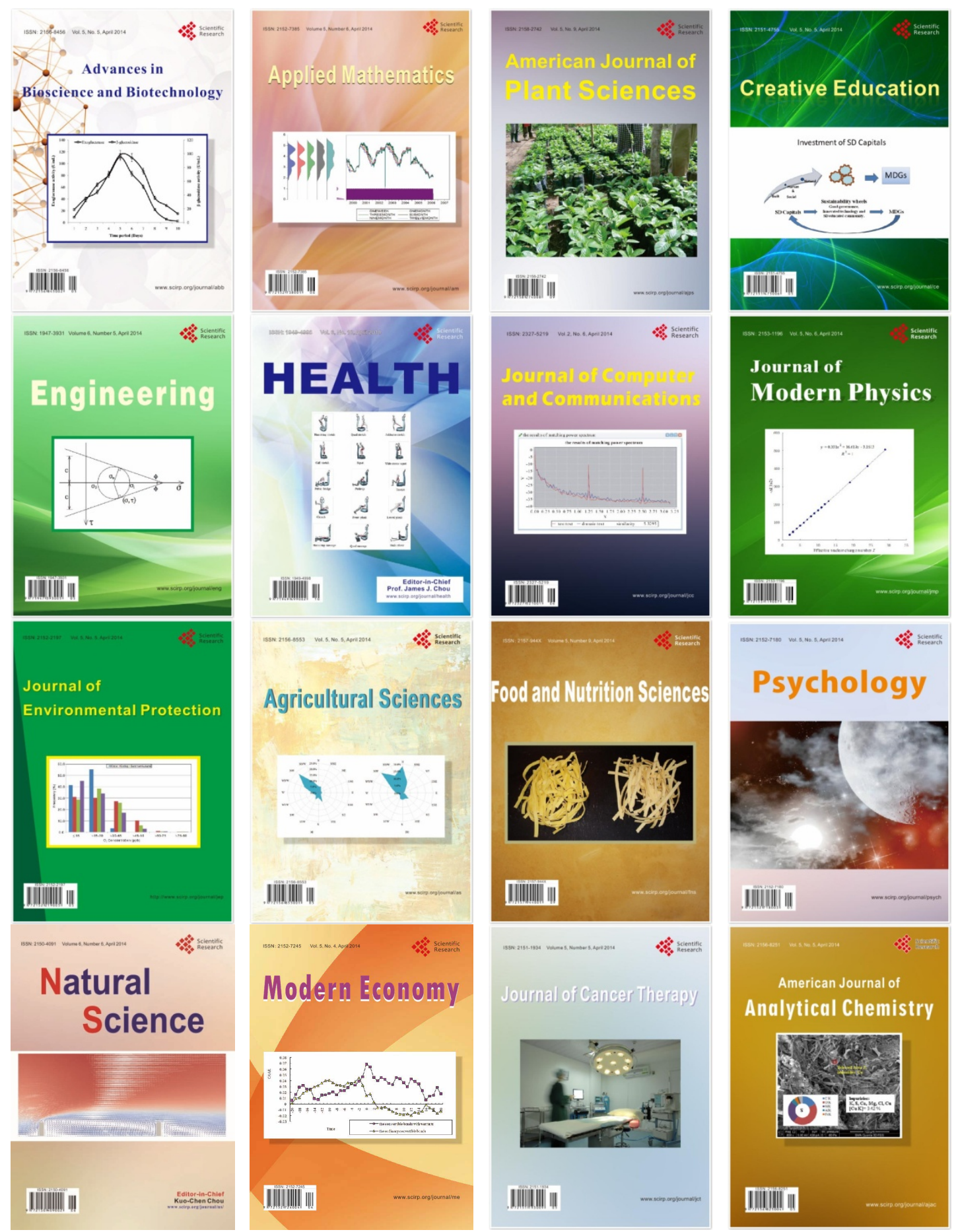